\title{
DIGITAL STORAGE AND ONLINE MEDIATED MEMORY
}

\author{
BALTEZAREVIC Borivoje ${ }^{1}$, MILUTINOVIC Olivera ${ }^{2}$, \\ BALTEZAREVIC Radoslav ${ }^{3}$, BALTEZAREVIC Vesna ${ }^{4}$
}

\author{
${ }^{1}$ Faculty of Management, Sremski Karlovci (SERBIA) \\ ${ }^{2}$ Faculty of Management, Sremski Karlovci (SERBIA) \\ ${ }^{3}$ Cyprus International Institute of Management - CIIM, Nicosia (CYPRUS) \\ ${ }^{4}$ Faculty of Law, Belgrade, Megatrend university (SERBIA) \\ Emails: baltezb@yahoo.co.uk, olivera.milutinovic@famns.edu.rs,rbaltezarevic@gmail.com,vesnabal@gmail.com
}

\begin{abstract}
This paper addresses the research of digital media users' attitudes towards digital storage and online mediated memory. Digital storage leads to the replacement of analog information by computer numerical coding and dematerializes media text and photos by converting data from analogue to digital. Main foci are on the examination of the digital media users' behavior in relation to the sharing of their own memories and culture, as well as their relation to the possibility of creating joint memories, common identity and collective culture. The paper also points to a culture of forgetting that accompanies the process of memory mediating.
\end{abstract}

Keywords: collective culture, common identity, computer numerical coding, digital media, digital storage,

memory mediating, users' attitudes

JEL: A30, 033, 035

UDC: $316.77: 004.004 .738 .5: 316$

COBISS.SR-ID: 18170377

\section{Introduction}

Digital storage, which is not durability-oriented, is associated with a completely new dimension of memory erasure, which leads to the replacement of analog information by computer numerical coding.

"In the process of mediating of human memory to external media (HDD, flash, cloud, social network), we are simultaneously delegating a part of our humanity, because virtual reality in anthropological and sociological terms represents a technical means for indirect production of reality, which establishes full control over man and his actions" [1]. Digital storage is associated with an entirely new dimension of memory erasure, which leads to the replacement of analog information by computer numerical coding.

Digitality is the most prominent feature of new media that dematerializes media text by converting data from analogue to digital, allowing all kinds of mathematical operations.

Digital media, as "a digital content that can be broadcasted on the Internet or computer network" [2], allow downloading and handling of large amounts of information, as well as its storage in a very limited space.

The power of convergence of digital media can be easily demonstrated through the emergence of the Internet in the context of its powerful function contained in computerinformation technologies and broadband communications networks.

The interactive function of digital media, realized between users and systems regarding the use of information resources, gives users great freedom in the production and reproduction of content and form of information during interaction. 
The hypertextuality of digital media enables a global networking center where information is free to move and interconnect spontaneously. It has begun to build a new life experience for human beings, which in turn leads to the transformation of economic activities, cultural patterns, interactive styles and other aspects of human society [3].

However, the formation of a virtual community that transcends all boundaries of human society will definitely conflict with the way we experience reality and traditionally defined identity [4]. Historically, since the mediation of culture between humanity and nature, we have come to its mediation between humanity and the machine. The development of Web 2.0 technology has led to an explosive growth in the number of community-focused applications in the areas of social navigation, collaborative content editing, bookmarking, and tagging.

"Memory is a collective function" [5], which also has the function of social order parameters. In order for memory to survive, communication's skills are necessary. When a person communicates, he or she participates in the construction and preservation of collective memory.

Cultural memory is manifested through media and platforms that contain and transmit memory and represent the field of cultural negotiation through which different stories compete for their place in history. However, new digital platforms are raising the question: "Could digital file formation and 'automatic knowledge processing' be a generalization of amnesia, which will be the final achievement of the oblivion industry, when all analog information (audiovisual and other) will be replaced with numeric computer coding of speech and pictures?" [6].

As much as modern society may or may not be ready for a new form of memory storage, it is a fact that Internet users are increasingly opting for 'Mediated memory', as the activities and objects produced and appropriated through the means of media technologies, for creating and re-creating a sense of the past, present, and future of ourselves in relation to the media [7]. As technology platforms quickly become obsolete, there is a tendency for digital documents to be transmitted across multiple platforms, for fear of losing digital content.

The first part of the paper gives an overview of the relevant literature and previous considerations on the basis of which the research hypotheses are set. In the second part, the researchers introduce the methodology and the results of the tested hypotheses. In the conclusion, the researchers discuss and analyze the experimental results.

\section{Theoretical Background}

\section{The Technological Storage of Personal Memory}

As modern life is technologized and mediated [8], memory formation is increasingly structured on digital networks, which is why memory has characteristics both technological and human [9], [10], with differences between distributive digital network logic and physical memory storage logic.

Conceptualizations of memories rely on understanding of the cultural forms as practices of memorization and can be traced back to earlier metaphors that assume a connection between space and mental categories [11], which included the mental arrangement of images and places as a means of accommodating knowledge so that it would not be forgotten [12]. "These mediated memory artifacts recorded by individuals provide a place to consider the nature of collective history and memory" [13].

Forgetting is significant, because it removes parts of memory that, if remembered, can be harmful or useless, both to individuals and society; we can define forgetting as a function of providing internal memory coherence and canceling unnecessary memory sequences, leading to openness to change and to the future. 


\section{Digital Memory}

Digital memory cannot be equated with the storage space alone. It's a flexible memory we can store what we want, in the ways we want to, the quantity we want and the quality we want. Digital archives collect stories that may not be historically significant but are significant to those who want to remember them [14]. "While collective memory endures and draws strength from its base in a coherent body of people, it is individuals as group members who remember" [15].

This understanding relies on the 'mediated memory', as the activities and objects we produce and appropriate through the means of media technologies, for creating and recreating a sense of past, present, and future of self in relation to media [16] as 'without the capability to form autobiographical memory, we are unable to create a sense of continuity in our personhood' [17]. Digital media enables the convergence of typically different memory characteristics and actors, which in turn leads to the formation of a new form of memory, referred to as joint memory, which unites two different types of memory 'common memory' and 'shared memory' [18]. Thus, thanks to digital social spaces, 'the archive becomes an eminently social practice, a veritable living memory' [19].

"The culture of remembering is, in the digitalization process, facing its opposite which is directly the consequence of the digitization process - the culture of forgetting. Digital storage as temporary storage of memory is associated with a whole new dimension of memory erasure since analog information is transformed into computer-mediated numerical coding" [20].

On the basis of previous theoretical review, the following hypothesis has been set:

$\mathrm{H} 1$ : Exchange of individual memories of digital media users leads to the formation of "joint memory".

\section{Digital Amnesia}

Digital media consumers often are transferring their information to digital devices.

"Kaspersky Lab has named this phenomenon Digital Amnesia: the experience of forgetting information that you trust a digital device to store and remember for you" [21]. With the spread of digital media and their spread into almost every area of our lives, data is collected everywhere and is permanently stored. "The act of forgetting is of core importance for every individual, but also for social and cultural interactions as we know them today" [22].

Data is thus deposited on the networks, regardless of whether they are important or not, because the network "stores any published information" [23]. "The fact that this form of memory is autobiographical and collective, private and public, user and platform generated leads to new problems of control over one's own archives" [24], indicates that "forgetting is constitutive in the formation of a new identity" because the network participant deliberately erases aspects of his past in order to construct a new identity and to adapt to a common identity [25].

There is a difference between individual memory, which has a neurological basis, and collective memory that is "based on the structures and processes through which human collectivities (social communities) establish culture" [26]. Maurice Halbwachs was the first to define the memory of a society as a collective memory that combines social and historical memory and individual memory as "personal" and "autobiographical" memory [27].

At the time of digitalization, identity becomes constantly changing, continually forming and transforming in relation to the ways in which we present ourselves or to which we are addressed in the cultural systems that surround us [28]. Identification with other users of digital social networks is constructed on the basis of recognition of a common origin or common characteristics with a certain 'other' person or group, or ideal, within the natural context of solidarity and belonging established on these bases. 
On the basis of previous theoretical review, the following hypothesis has been set:

H2. Digital media users often remove previously deposited content, which they consider to be irrelevant, leading to adjusting to a common identity.

\section{Digital Photo Album}

"In cyberspace, we often have the opportunity to meet the complete lives of others" [29], because network users post not only various textual content but also photographs that expose their privacy to other cyberspace visitors. Digital photo uploading, initially conceived as a memory deposit, has evolved into a "more comprehensive tool for building online identity, connecting and communication" [30]. Depositing digital photos and sharing them gives the possibility to people to "shape their memories and identities" [31]. Social networks are becoming an ever-growing platform for displaying and sharing photos with the intention of introducing users to virtual friends, but they are also building their online identity [32]. The social network is identified with its own "digital album" because many of the users believe that the network has the role of a platform as a performance, exhibition, and personal archive [33].

\section{Digital Media as a Place for Storage of Cultural Memory}

"Digitizing intrapersonal communication brings about the simultaneous digatilization of culture and society" [34]. Memories stored on various digital media, especially on a social web site that can be accessed by Internet, users include features of an autobiographical and collective past. "Culture in transition to the digital age is transformed into a culture of forgetting, preserving the existing traditional cultural values" [35].

The pluralisation and fragmentation of the processes of individual and collective memory that have found a place for expression and promotion in social media is the result of collaborative work among users. "The social web has shown itself to be a place for grassroots cultural memory when its forms of writing take on legitimacy analogous to that of official sources of collective remembering - or at least a competing, competitive legitimacy" [36].

The openness of digital media to the creation of content by users, using modern information and communication technologies, creates a platform for the exchange of culture.

Individual cultural memories face cultural differences that may include different languages, national traditions and cultural values [37] they considered human-related factors such as trust [38] and interpersonal relationships [39].

The fact is that the global population is rapidly entering the Internet. Data shows that there are 4.39 billion Internet users and 3.48 billion social media users in 2019 [40]. They all bring their personal culture and cultural memories online. "Delegation of remembering to external databases is a simultaneous threat not only to the depth and uniqueness of the self but also to the depth and uniqueness of the culture we all partake in" [41]. "Community members are usually strangers to each other" [42], but online they become 'friends' to share memories with. The network is constantly creating a new kind of culture, which is a mix of introduced and exchanged cultures, namely the collective culture as well as the collective memory.

On the basis of previous theoretical review, the following hypothesis has been set:

H3: Sharing cultural values on social networks leads to the creation of a collective culture.

\section{Methodology}

\section{Research Objectives}

The research was conducted with the purpose of identifying respondents' attitudes regarding the claims made by the authors in the questionnaire, in order to test the hypotheses 
that were informed by the literature analyzed in this paper. The following hypotheses were set:

H1: Exchange of individual memories of social media users leads to the formation of joint memory.

H2. Social media users often remove previously deposited content, which they consider to be irrelevant, which leads to the adjustment to a common identity.

H3: Sharing cultural values on social networks leads to the creation of a collective culture.

\section{Data Collection}

The first part of the questionnaire consisted of questions related to respondents' demographic profile (gender, age and level of education). The second part was used to test respondent's attitudes which were measured using 5-point Likert-type scales, anchored from 5 $=$ "Strongly agree" to 1 = "Strongly disagree".

Data collected from September to October 2019. was sent to 450 e-mail addresses of faculty employees on the territory of the Republic of Serbia. Until the end of September 2019, 392 questionnaires were received. For further analysis, the authors selected 349 properly filled questionnaires. Further analysis eliminated questionnaires in which respondents stated that they did not use social networks.

\section{Basic Descriptives}

\begin{tabular}{|c|c|c|}
\hline Demographic & $\mathrm{n}$ & $\%$ \\
\hline \multicolumn{3}{|l|}{ Gender } \\
\hline Male & 179 & 51.3 \\
\hline Female & 170 & 48.7 \\
\hline \multicolumn{3}{|l|}{ Age } \\
\hline $18-25$ & 119 & 26.4 \\
\hline $26-35$ & 92 & 26.4 \\
\hline $36-45$ & 66 & 18.9 \\
\hline $46-55$ & 38 & 10.9 \\
\hline $56-65$ & 14 & 4.0 \\
\hline \multicolumn{3}{|l|}{ Education } \\
\hline High School & 73 & 20.9 \\
\hline University & 135 & 38.7 \\
\hline MBA & 63 & 18.1 \\
\hline $\mathrm{PhD}$ & 78 & 22.3 \\
\hline
\end{tabular}

Table 1 shows a basic description of the sample. Both genders are almost equal in representation with a slightly higher percentage in favor of male respondents. The survey participants were mostly below $18-25$ years of age $(26.4 \%)$, with University education $(38.7 \%)$.

\section{Results and Discussion}

To test the hypothesis in this paper, authors made a list of six variables and tested the internal reliability of thus formed scale using the Kronbah (Cronbach) alpha analysis. The scale showed high reliability and internal consent since Cronbach's Alpha for the scale has shown that $\alpha=.906$. Kolmogorov-Smirnov's tests of Normality (Sig. $<0.05$ ), has directed the 
use of nonparametric techniques for further research, so we have applied a chi-square test and Spearman's rank-order correlation.

H1: Exchange of individual memories of social media users sharing leads to the formation of joint memory.

The chi-square test of independence has shown that there is a statistically significant correlation between the attitudes of respondents on the issue that the exchange of individual memory of social media users leads to the formation of joint memory.

The relationship between these variables was $\chi 2(16,1)=306.567, p<0.01$. Spearman's correlation of rank Rho $=.575$ shows that this is a positive high correlation. $\mathrm{R} 2=.322$, which indicates that $32.2 \%$ of respondents' views regarding the claim that network users exchange individual memories explains respondents' views regarding the claim that sharing individual memories leads to the creation of joint memory.

H2. Social media users often remove previously deposited content, which they consider to be irrelevant, leading to adjusting to a common identity.

The chi-square test of independence has shown that there is a statistically significant correlation between the attitudes of respondents on the issue that Social media users often remove previously deposited content, which they consider to be irrelevant, leading to adjusting to a common identity.

The relationship between these variables was $\chi 2(16,1)=398.269, \mathrm{p}<0.01$. Spearman's correlation of rank Rho $=.490$ indicates that this is a positive moderate correlation. $\mathrm{R} 2=.239$ means that $23.9 \%$ of respondents' views regarding the claim that social media users often remove previously deposited content, which they consider to be irrelevant explains respondents' views regarding the claim that removing previously deposited content leads to adjusting to a common identity.

H3: Sharing cultural values on social networks leads to the creation of a collective culture

The chi-square test of independence has shown that there is a statistically significant correlation between the attitudes of respondents on the issue that sharing cultural values on social networks leads to the creation of a collective culture.

The relationship between these variables was $\chi^{2}(16,1)=190.990, p<0.01$. Spearman's rank correlation Rho $=.494$ indicates that this is a positive moderate correlation. $\mathrm{R} 2=.252$ means that $25.2 \%$ of respondents' attitudes regarding the claim that social network users share cultural values on social networks explains respondents' attitudes regarding the statement that sharing cultural values leads to the creation of a collective culture.

\section{Conclusion}

The purpose of this research was to examine social network users' attitudes towards mediated memory. The paper also points to a culture of forgetting that accompanies the digital storing of memory.

The first hypothesis is confirmed, as the results of the research have shown that there is a connection between the attitudes of the respondents on the issue that sharing of individual memory of social media users leads to the formation of joint memory.

The second hypothesis is confirmed as the results of the research have shown that there is a connection between the attitudes of the respondents on the issue that social media users often remove previously deposited content, which they consider to be irrelevant, leading to the adjusting to a common identity.

The identity of digital media users and their presentation on social networks are subject to constant change. User identities brought from offline communities, influenced by exchanges of cultural values and different beliefs, are constantly being modified and adjusted to common identities. In order to be completely immersed in common identity, users make adjustments to 
their profiles in the sense that they delete some of the earlier content that represented their identity because these characteristics deviate from understanding what a common identity pattern on the web should be. However, this is not only a question of correcting content, but also of erasing the past and adjusting it to a new identity which constructs digital amnesia.

The third hypothesis is also confirmed as the results of the research have shown that there is a connection between the attitudes of the respondents on the issue that sharing cultural values on social networks leads to the creation of a collective culture.

Digatilization of culture and society and mediated stored memories from autobiographical and collective culture can easy be "transformed into a culture of forgetting, preserving the existing traditional cultural values" [43].

When identity and culture are interpreted as variables, it is also reflected in the phenomenon of cultural identity that also becomes a subject to change. In an age of online living and technologically mediated communication, there is a need to diverge from the traditional character of peoples and cultures in relation to the need for the individual to adapt to a common culture.

\section{REFERENCES}

[1] Koković, D. (2007). Društvo i medijski izazovi: uvod u sociologiju masovnih komunikacija. Novi Sad: Filozofski fakultet, 179.

[2] Maurya, A. (2019). WHAT IS DIGITAL MEDIA https://www.quora.com/What-is-digital-media-2

[3] Castells, M. (2000). Materials for an exploratory theory of the network society. British Journal of Sociology, 51(1), 5-24. https://doi.org/10.1111/j.1468-4446.2000.00005.x

[4] Jones, S.G. (Ed.). (1995). Cybersociety: Computer-mediated communication and community. Thousand Oaks, CA: Sage.

[5] Halbwachs, M. (1992). On Collective Memory, Trans. Lewis A. Coser. Chicago: University of Chicago Press, p. 183.

[6] Virilio, P. (2000). Informatička bomba. Novi Sad: Svetovi, p. 122.

[7] van Dijck, J. (2007) Mediated memories in the digital age. Stanford: California, p. 21.

[8] Lash, S. (2007) "Power after Hegemony: Cultural Studies in Mutation?" Theory, Culture \& Society, 24 (3), pp. 55-78. https://doi.org/10.1177/0263276407075956

[9] van Dijck, J. (2010). "Flickr and the Culture of Connectivity: Sharing Views, Experiences, Memories". Memory Studies, 4(4): pp. 401-415. https://doi.org/10.1177/1750698010385215

[10] Reading, A. (2012) 'Globital Time: Time in the Digital Globalised Age' in E. Keightley (ed.) Time, Media and Modernity, pp. 143-161, New York: Palgrave Macmillan, p. 144.

[11] Frow, J. (2007). 'Toute la Mémoire du Monde: Repetition and Forgetting'. In M. Rossington \&A. Whitehead (Eds.), Theories of Memory: A Reader (pp. 150-156). Edinburgh: Edinburgh University Press, p. 152

[12] Yates, F. (1966). The Art of Memory. London: Routledge and Kegan Paul, 3.

[13] Hume, J. (2010). Memory Matters: The Evolution of Scholarship in Collective Memory and Mass $\begin{array}{lllll}\text { Communication. The Review of } & 187 .\end{array}$ https://doi.org/10.1080/15358591003632563

[14] Garde-Hansen, J., Andrew, H. \& Reading, A. (2009). Save As: Digital Memories. New York: Palgrave Macmillan, p. 12.

[15] Halbwachs, M. (1992). On Collective Memory. Trans. Lewis A. Coser. Chicago: University of Chicago Press, p. 48.

[16] van Dijck, J. (2007) Mediated memories in the digital age. Stanford: California, p. 21.

[17] van Dijck, J. (2007) Mediated memories in the digital age. Stanford: California, p. 2.

[18] Ashuri, T. (2011). 'Joint memory: ICT and the rise of moral Mnemonic agents' (pp. 104-113) in Neiger, M., Meyers, O., Zandberg, E. (Eds.) On Media Memory: Collective Memory in a New Media Age. London: Palgrave Macmillan, p. 105.

[19] Pinchevski, A. (2011). 'Archive, Media, Trauma'. In M. Neiger, O. Meyers, \& E. Zandberg (Eds.), On Media Memory: Collective Memory in a New Media Age (pp. 253-264). London: Palgrave Macmillan, p. 254.

[20] Baltezarević, B., Baltezarević, R. \& Baltezarević, V. (2018). Culture in new media times". Informatologia, 51 (pp. 3-4), 202. https://doi.org/10.32914/i.51.3-4.8 
[21] Kaspersky Lab (2015), The rise and impact of Digital Amnesia, https://blog.kaspersky.com/files/2015/06/005-Kaspersky-Digital-Amnesia-19.6.15.pdf), 4.

[22] Bannon, L. (2004). Forgetting as "A feature not a bug" - the duality of memory and implications for ubiquitous computing. CoDesign International Journal of CoCreation in Design and the Arts, 2(1), 6.

[23] Zeger, H.G. (2009). Paralleluniversum Web 2.0 - Wie Online-Netzwerke unsere Gesellschaft verändern. Wien: Kremayr \& Scheriau, 84.

[24] Connerton, P. (2008) 'Seven types of forgetting'. Memory Studies 1(1), 63. https://doi.org/10.1177/1750698007083889

[25] Connerton, P. (2008) 'Seven types of forgetting'. Memory Studies 1(1), 63. https://doi.org/10.1177/1750698007083889

[26] Nikodijević, D. \& Đukanović, J. (2014). Ne(moć) komunikacije kulturnog nasleđa sa okruženjem sumrak tradicije u tržišnoj i digitalnoj epohi; Zbornik radova sa međunarodnog naučnog skupa Moć komunikacije. Banja Luka: Panevropski univerzitet APEIRON, 100.

[27] Halbwachs M (1980) [1950] The collective memory (translated by Francis JD Jr, Vida YD). Reprinted by Harper Colophon, pp. 50-52.

[28] Hall, S. (1992). The question of cultural identity, in Hall, Stuart; Held, David; McGrew, Anthony, Modernity and its futures, Cambridge: Polity Press in association with the Open University.

[29] Baltezarević, V., Baltezarević, R. \& Baltezarević, B. (2016). Who controls the controllers of the internet? Journal of Systems Applications, Engineering \& Development, North Atlantic University Union, Volume 10, p. 324.

[30] Eftekhar, A., Fullwood, C. \& Morris, N. (2014). Capturing personality from Facebook photos and photo-related activities: how much exposure do you need? Computers in Human Behavior, 37, pp. 162170. https://doi.org/10.1016/j.chb.2014.04.048

[31] van Dijck, J. (2008). Digital photography: communication, identity, memory. Visual Communications, 7(1), 60. https://doi.org/10.1177/1470357207084865

[32] McLaughlin, C. \& Vitak, J. (2012). Norm evolution and violation on Facebook. New Media \& Society, 14(2), pp. 299-315. https://doi.org/10.1177/1461444811412712

[33] Zhao, X., Salehi, N., Naranjit, S., Alwaalan, S., Voida, S. \& Cosley, D. (2013). In Proceedings of the SIGCHI Conference on human factors in computing systems (CHI 13), New York, NY, pp. 1-10.

[34] Baltezarević, B., Baltezarević, R. \& Baltezarević, V. (2018). Culture in new media times. Informatologia, 51 (3-4), 200. https://doi.org/10.32914/i.51.3-4.8.

[35] Baltezarević, B., Baltezarević, R. \& Baltezarević, V. (2018). Culture in new media times". Informatologia, 51 (3-4), 200. https://doi.org/10.32914/i.51.3-4.8.

[36] Bartoletti, R. (2011). Memory and Social Media: New Forms of Remembering and Forgetting in B. Pirani (Ed), "Learning from Memory: Body, Memory and Technology in a Globalizing World" (pp. 82111). Newcastle UK: Cambridge Scholars Publishing, 99.

[37] Carmel, E. \& Agarwal, R. (2002) The maturation of offshore sourcing of information technology work. MIS Quarterly Executive, 1, pp. 65-77. DOI:10.1007/978-3-540-34877-1_22

[38] Ridings, C., Gefen, D. \& Arinze, B. (2002) Some antecedents and effects of trust in virtual communities. Journal of Strategic Information Systems, 11, 272. DOI: 10.1016/S0963-8687(02)000215

[39] Ahuja, M.K. \& Galvin, J.E. (2003). Socialization in virtual groups. Journal of Management, 29, pp. 161-185. DOI: 10.1177/014920630302900203

[40] Kemp, S. (2019). Global digital reports. Retrieved from https://wearesocial.com/blog/2019/01/digital2019-global-internet-use-accelerates

[41] Kar, N. (2013). Plitko. Kako internet menja način na koji mislimo, čitamo i pamtimo. Smederevo: Heliks, 199.

[42] Ridings, C., Gefen, D. \& Arinze, B. (2002) Some antecedents and effects of trust in virtual communities. Journal of Strategic Information Systems, 11, 272. https://doi.org/10.1016/S09638687(02)00021-5

[43] Baltezarević, B., Baltezarević, R. \& Baltezarević, V. (2018). Culture in new media times”. Informatologia, 51 (3-4), 200. https://doi.org/10.32914/i.51.3-4.8

\section{Article history:}

Received 1 February 2020

Accepted 17 May 2020 